\title{
Communication
}

[Comunicação]

\section{Frequency of equine viral arteritis in Minas Gerais State, Brazil}

[Freqüencia da arterite viral eqüina no estado de Minas Gerais, Brasil]

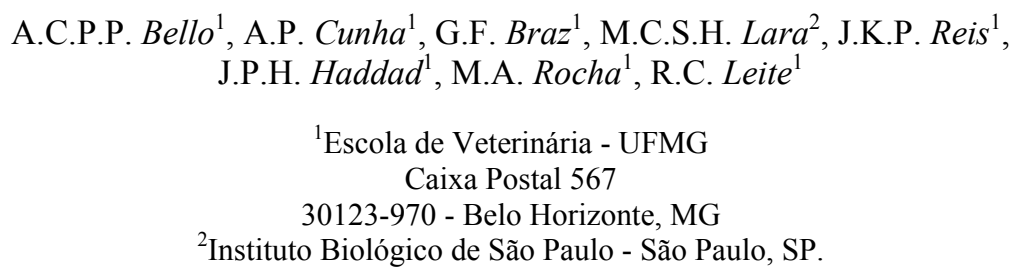

Equine viral arteritis (EVA) is caused by a virus from family Arteriviridae and is connected to respiratory disease and abortion (Doll et al., 1957). Serologic evidence suggests that natural infection occurs in equids (Paweska et al., 1995).

In Brazil, the first outbreak occurred in 1993, in the city of Ibiuna, São Paulo State, in an estate where Mangalarga Paulista horses were raised. From the results of serum neutralization paired tests, showing the serum conversion with presence of anti-equine arterites virus (EAV) antibodies, the disease was detected (Fernandes et al, 1997). This study was carried out to estimate the frequency and distribution of EVA, in 10 Regional Offices of the Instituto Mineiro de Agropecuária (IMA) in Minas Gerais State, by serum-neutralization technique as a way to support future approaches to control the disease.

Eight hundred and twenty-six serum samples from equids were collected in 10 Regional Offices. Each Regional Office of IMA represents a group of cities from a microregion, determined in accordance with the central office localization. Blood was collected through punction in jugular vein and stored in sterile test tubes. After coagulation, the serum were separated, identified and stored frozen at $-20^{\circ} \mathrm{C}$ for processing at the Laboratório de Virologia do Instituto Biológico de São Paulo.

The used methodology was the microplate serum-neutralization technique described by Senne et al. (1985). The standard sample for

Recebido em 13 de setembro de 2006

Aceito em 17 de maio de 2007

E-mail: anabello@pop.com.br

Apoio: FAPEMIG.
EAV used in the test was the strain CVLBucyrus (donated by Dr. Peter Timoney ${ }^{1}$ and kept at the Instituto Biológico de São Paulo). The strain was multiplied in rabbit kidney cells (RK13).

Seven $(0.85 \%)$ out of the 826 equids serum samples were positive for equine arteritis virus considering the 10 Regional Offices of IMA (Table 1).

Despite the low percentage of positive animals found, the presence of the virus in Minas Gerais State should be regarded as a major epidemiologic factor, mainly considering that equineculture in that State is the biggest in Brazil (Pesquisa..., 2000) and the intense transit of animals for exhibitions, contests and fairs. Data presented by Souza (1996) for São Paulo State, allowed the observation that the seropositivity rates found in the border region between São Paulo and Minas Gerais are higher than the total seropositivity rate (Campinas, 24.6\%; São José dos Campos, 24.4\% and Ribeirão Preto, 15.4\%).

These results are close to that obtained by Souza et al. (1999) that reported $1.04 \%$ in the region of Vale do Paraíba, São Paulo State. While Souza (1996) found a seropositivity rate of $18.2 \%$ in equines for São Paulo State, Silva et al. (1999) and Heinemann et al. (2002) did not find seropositivity in their respective studies.

${ }^{1}$ Researcher at Gluck Equine Research Center - Kentucky (EUA) 
Table 1. Results of serum neutralization tests for equine viral arteritis carried out in samples collected in 10 Regional Offices of IMA in Minas Gerais State

\begin{tabular}{lccccc}
\hline \multirow{2}{*}{ Regional office } & \multicolumn{5}{c}{ Result } \\
\cline { 2 - 6 } \multicolumn{1}{c}{ Number of animals } & Reactive & $\%$ & Non-reactive & $\%$ \\
\hline Almenara & 130 & 1 & 0.77 & 129 & 99.23 \\
Bambuí & 44 & 0 & 0.0 & 44 & 100 \\
Curvelo & 88 & 0 & 0.0 & 89 & 100 \\
Gov. Valadares & 47 & 0 & 0.0 & 47 & 100 \\
Montes Claros & 92 & 1 & 1.09 & 91 & 98.91 \\
Oliveira & 47 & 1 & 2.12 & 46 & 97.87 \\
São Gonçalo do Sapucaí & 45 & 1 & 2.22 & 44 & 97.78 \\
Teófilo Otoni & 147 & 2 & 1.36 & 145 & 98.64 \\
Unaí & 128 & 0 & 0.0 & 128 & 100 \\
Viçosa & 58 & 1 & 1.72 & 57 & 98.28 \\
Total & 826 & 7 & 0.85 & 819 & 99.15 \\
\hline
\end{tabular}

The frequencies of EAV infection found for each studied species were: equines $0.80 \%(6 / 749)$; asinines $25 \%(1 / 4)$ and muars $0 \%$. As for the muars and asinines, it was not found data on animal EAV seropositivity in Brazil (Heinemann et al., 2002). Though there were no reports of EVA natural transmission among equid species, the potential epidemiologic risk of viral dissemination must be considered (Paweska et al., 1996; Paweska et al., 1997).
By the detection of anti-EAV antibodies, the contact of equids with equine arteritis virus was established in seven out of the 10 Regional Offices investigated in Minas Gerais State. The EVA should be considered in the investigative routines for the differential diagnosis of respiratory disorders and abortions in equines in Minas Gerais State.

Keywords: equids, equine viral arteritis, Minas Gerais State

\section{RESUMO}

Verificou-se a freqüência e a distribuição de eqüídeos soropositivos para arterite viral eqüina (AVE) em 10 Delegacias Regionais do IMA no estado de Minas Gerais, por meio da técnica soroneutralização. A taxa de animais reagentes foi 0,85\% (7/826) e em cada Delegacia Regional: Almenara (0,77\%), Montes Claros (1,09\%), Oliveira (2,12\%), São Gonçalo do Sapucaí (2,22\%), Teófilo Otoni (1,36\%) e Viçosa $(1,72 \%)$. O presente estudo indica a presença de animais soropositivos para AVE em diferentes regiões do estado de Minas Gerais.

Palavras-chave: eqüino, arterite viral eqüina, Minas Gerais

\section{REFERENCES}

DOLL, E.R.; KNAPPENBERGER, R.E.; BRYANS, J.T. An outbreak of abortion caused by the equine arteritis virus. Cornell Vet., v.47, p.69-75, 1957.

FERNANDES, W. R.; SOUZA, M. C. C.; TIMONEY, P. J. et al. Ocorrência de surto de arterite viral dos eqüinos no Brasil. In: CONFERENNCIA ANUAL DA SOCIEDADE PAULISTA DE MEDICINA VETERINÁRIA, 52, 1997, São Paulo. Anais..., São Paulo: Sociedade Paulista de Medicina Veterinária, 1997. p.14 (resumo).

HEINEMANN, M.B.; CORTEZ, A; SOUZA, M.C.C. et al. Soroprevalência da anemia infecciosa eqüina, da arterite viral dos eqüinos e 
do aborto viral eqüino no município de Uruará, PA, Brasil. Braz. J. Vet. Res. Anim. Sci., v.39, p.50-53, 2002.

LARA, M.C.C.S.H.; BARROS FILHO, I.; VIANA, F. et al. Pesquisa de anticorpos contra o vírus da arterite dos eqüinos (VAE) e herpes eqüino tipo 1 (HVE-1) em cavalos criados em Curitiba, PR. Hora Vet., Porto Alegre, v.23, p.26-28, 2003.

PAWESKA, J.T.; AITCHISON, H.; BARNARD, B.J.H.; CHIRNSIDE, E.D. Transmisssion of the south-african asinine strain of equine arteritis virus among horses and between donkeys and horses. J. S. Afr. Vet. Assoc., v.63, p.189-196, 1996.

PAWESKA, J.T.; BINNS, M.M.; WOODS, P.S.A.; CHIRNSIDE, E.D. A survey for antibodies to equine arteritis virus in donkeys, mules and zebra using virus neutralization (VN) and enzyme linked immunosorbent assay (ELISA). Equine Vet. J., v.29, p.40-43, 1997.

PESQUISA da Pecuária Municipal. Efetivo dos rebanhos, segundo as Mesorregiões, Microrregiões e os Municípios. Rio de Janeiro: IBGE, 2004. Disponível em:
$<$ ftp://ftp.ibge.gov.br/Producao_Pecuaria/Produ cao_da_Pecuaria_Municipal_\%5Banual\%5D/20 04/>. Acessado em: $12 \mathrm{dez} .2005$.

SENNE, D.A.; PEARSON, J.E.; CARBREY, E.A. Equine viral arteritis: a standard procedure for the virus neutralization test and comparison of results of a proficiency test performed at five laboratories. Proc. U. S. Anim. Health Assoc., v.89, p.29-34, 1985.

SILVA, R.A.M.S.; DÁVILA， A.M.R.; IVERSSON, L.B. et al. Equine viral diseases in the Pantanal, Brazil. Studies carried out from 1990 to 1995. Rev. Elev. Med. Vet. Pays Trop., v.52, p.9-12, 1999.

SOUZA, M.C.C. Prevalência da infecção pelo vírus da arterite dos eqüinos em cavalos criados no estado de São Paulo. 1996. 81f. Dissertação (Mestrado) - Faculdade de Medicina Veterinária e Zootecnia, Universidade de São Paulo, São Paulo.

SOUZA, M.C.C.; CUNHA, M.C.A.M.; GREGORY, L. Pesquisa de anticorpos contra o vírus da arterite dos eqüinos em cavalos criados no Vale do Paraíba, SP. Arq. Inst. Biol., v.66, supl., p.40, 1999. 